Таким образом, за небольшой период времени в Набережных Челнах произошла реорганизация органов самоуправления, которая олицетворяет классический пример функционирования ОМСУ в СССР.

$$
* * *
$$

1. Конституция (Основной закон) Союза Советских Социалистических Республик (утверждена постановлением Чрезвычайного VIII Съезда Советов Союза Советских Социалистических Республик от 5 декабря 1936 г.) (в редакции от 12 февраля 1957 г.) // Сайт Конституции Российской Федерации [Электронный доступ]. - URL: http://constitution.garant.ru/history/ussr-rsfsr/1936/red_1936/3958676/ (дата обращения 03.12.2021)

2. Архивный отдел управления делопроизводства Исполнительного комитета муниципального образования город Набережные Челны Ф. №166, О. №1, Ед. Хр. №97-98.

3. Айсин, Р.Г. В золотых огнях гидростанции...: справочное издание / Р.Г. Айсин, Т.Б. Денчик, М.М. Лапшин. Набережные Челны: Набережночелнинская типография, 1999. - 136 с.

4. История города Набережные Челны. На рубеже 50-60-х гг. [Электронный доступ]. - URL: https://chelnystory.clan.su/publ/xx_vek/na_rubezhe_50_-60_kh_gg/7-1-0-31 (дата обращения 09.12.2021)

5. Караваева И.В. Расширение финансовой самостоятельности местной власти в СССР в военные и послевоенные годы: малоизвестные факты из истории Великой Отечественной войны // Вестник Института экономики Российской академии наук. 2015. №4. URL: https://cyberleninka.ru/article/n/rasshirenie-finansovoysamostoyatelnosti-mestnoy-vlasti-v-sssr-v-voennye-i-poslevoennye-gody-maloizvestnye-fakty-iz-istorii-velikoy (дата обращения: 15.12.2021)

6. Мухаметов Р. С. «Советская» система местного самоуправления в России и ее особенности // Муниципалитет: экономика и управление. 2019. №2 (27). URL: https://cyberleninka.ru/article/n/sovetskayasistema-mestnogo-samoupravleniya-v-rossii-i-ee-osobennosti (дата обращения: 03.12.2021)

7. Энциклопедия города Набережные Челны / Под ред. Б.Л. Кузнецова, М.Ш. Бибишева, Б.А. Канеева. Казань: Издательство «Идел-Пресс», 2007. - 464c.

\title{
Упоров И.В. \\ Главы земств и городов в системе местного самоуправления России XVI-XIX веков: организационно-правовой статус
}

Краснодарский университет МВД России (Россия, Краснодар)

doi: 10.18411/trnio-01-2022-11

\section{Аннотация}

Представлен краткий обзор развития института руководителей органов местного самоуправления в истории России, охватывавшей период с XVI по XIX века, на основе анализа соответствующих нормативно-правовых актов и ряда научных публикаций по заявленной теме. Отмечается, что в условиях монархической России хотя и предусматривались элементы выборности земских (губных) старост, а позже председателей земских (городских) управ, тем не менее, местное самоуправление функционировало под жестким контролем государства, а руководители органов местного самоуправления подбирались прежде всего по принципу лояльности действующей государственной власти и не имели собственных полномочий по решению вопросов местного значения.

Ключевые слова: земский староста, городской голова, местное самоуправление, власть, государство, общество, закон.

\section{Abstract}

The article presents a brief overview of the development of the institution of heads of local self-government bodies in the history of Russia, which covered the period from the 16th to the 19th centuries, based on an analysis of the relevant regulatory legal acts and a number of scientific publications on the stated topic. It is noted that in the conditions of monarchical Russia, although elements of the election of zemstvo (labial) elders, and later chairmen of zemstvo (city) councils were envisaged, nevertheless local self-government functioned under the strict control of the state, 
and the heads of local self-government bodies were selected primarily on the principle of loyalty to the current state power and did not have their own powers to resolve issues of local importance.

Keywords: zemstvo headman, mayor, local self-government, power, state, society, law.

Местное самоуправление как социально-правовой институт развивается в России на системном уровне, начиная с эпохи Екатерины Великой, когда было принято известное Городовое положение 1785 года. Но это не значит, что ранее не было вообще местного самоуправление - оно функционировало, но в бессистемных формах, то есть, по сути, практика только формировалась. Это касалось и института главы местного самоуправления, на историко-правовом развитии мы сосредоточиваем свое внимание, имея в виду период монархической России.

Отсчет, вероятно, целесообразно вести от XVI века, когда в Московии уже стали выделяться главы местной власти. В то время в Московском государстве уже функционировали губные и земские избы (первые своей функцией имели борьбу с преступлением и поддержанием правопорядка в определенной части воеводства, вторые ведали общими вопросам управления на соответствующей территории, обычно это был масштаб уезда). Губного старосту могли выбирать только свободные люди из дворяне и детей боярских. Однако в практике из этого правила имели место отступления, которые обуславливались рядом причин, в числе которых неудовлетворительная работа действующих старост, отсутствие подходящих кандидатур, не устраивающие власть результаты выборов старосты. В подобных случаях губной староста назначался тем приказов, в ведении которого находился уезд, где требовался староста. Значительное влияние на замещение должности губного старосты имел воевода, который, собственно, и предлагал кандидатуры. При этом старост, разумеется, должен был быть лояльным царской и воеводской власти, что отражало уже практически сложившийся к тому времени абсолютистский режим управления государством. Должность губного старосты в более или менее завершенном виде сложилась в ходе земской реформы 1551-1555 годов.

Функции и полномочия губного старосты закреплялись преимущественно в губных грамотах. Губной староста, приступивший к исполнению своих обязанностей, должен был нанести визит в Разрядный приказ, где происходило его утверждение в должности, приведение к присяге, там же он получал «наказ», то есть, по сути, должностную инструкцию.

Земские старосты в рамках земской реформы закреплялись прежде всего в земских уставных грамотах [1]. Реформа предусматривала возможность осуществления самоуправления непосредственно путем проведения сходов, на которых крестьянскими общинами выбирались должностные лица местного самоуправления, и прежде всего земский староста, который возглавлял земскую избу, состоявшую также из земского дьячка и целовальников. В отличие от губного института, земство снабжало своих избранников более разнообразными полномочиями, оставлял за собой право контроля за их деятельностью, осуществляя перевыборы земских властей и утверждая их отчеты, а также осуществляя текущий контроль при рассмотрении наиболее важных вопросов на местных сходах. Земские старосты также находились в зависимости от воевод и приказов [2, с. 163].

Очевидно, что институт земских (губных) старост можно расценивать прообраз глав муниципальных образований, которые функционируют в современной России согласно принятому в 2003 г. Федеральному закону «Об общих принципах организации местного самоуправления в Российской Федерации», причем важным представляется отметить то обстоятельство, что имеется общий признак, который заключается в выборности главы местной власти - с учетом, разумеется, того, что в XVI веке об избирательном праве приходится говорить с большой долей условности. В дальнейшем, однако, выборность, равно как и относительная самостоятельность губных(земских) старост, и без того находившиеся на сравнительно невысоком уровне, стали заменяться аппаратнобюрократическими методами замещения этих должностей. В значительной степени такой 
подход Московского государства был обусловлен усиливавшейся в нем централизацией системы управления. Речь идет, в частности, об отмеченной выше возросшей роли института воевод в государственном аппарате Московского государства как представителей центральной власти [3, с. 22]. Кроме того, нельзя не отметить использования методов государственного управления, привнесенных Петром I после его известного путешествия в Западную Европу - с одной стороны, реформатор привнес некоторые демократические элементы, а с другой стороны, в его интерпретации эти элементы должны были быть подчинены единой воле монарха. Поэтому, например, внедряемые при воеводах дворянские советы или выбор крестьянами волостных старост находились в жесткой зависимости от вышестоящих чиновников, назначаемых строго по иерархии [4, с. 629], при этом те же земские избы заменялись непривычными для России ратушами и магистратами и другими управленческими структурами по образцу западноевропейских стран. О таком подходе свидетельствует, в частности, тот факт, что именно при Петре I Россия трансформировалась в абсолютистское государство с наивысшей единоличной волей монарха [5, c. 185].

Далее, уже в императорской России, заметные изменения по рассматриваемой проблематике стали происходить в период царствования Екатерины II, которая существенным образом модернизировала в целом все государственное управление (достаточно назвать, к примеру, издание ею известных «Учреждения для управления губерний» 1775 года). В контексте нашей темы здесь важнейшее место занимает указанное выше Городовое положение (как самостоятельная часть более общего закона «Жалованной грамоты на права и выгоды городам») от 21 апреля 1785 года [6], предусматривающим передачу части властных полномочий в городам выборным структурам. Это на системном уровне было сделано впервые в России и обуславливалось прежде всего объективным процессом - развитием в России экономических отношений в городах (развитие торговли, ремесел, строительства и т.д.), в рамках которых стали появляться состоятельные люди без аристократического происхождения (купцы, промышленники), но влиятельные в связи с обладанием сравнительно больших капиталов, и игнорировать их корпоративное значение императрица уже не могла.

Соответственно передача им части властных полномочий в городах производилась путем учреждения самоуправленческих структур. Так, в ст. 157 этого акта указывалось, в частности, что Городскую общую думу составляют «Городской голова и гласные от настоящих городовых обывателей, от гильдий, от цехов, от иногородных и иностранных гостей, от имянитых граждан и от посадских» [6]. Вместе с тем в этом законе не выделялись нормы о правовом статусе городского головы. Из содержания норм Городового положения следует, что Городская дума являлась коллегиальным органом местного самоуправления, соответственно городской голова не мог иметь собственных полномочий по решению вопросов городского значения, и являлся, выражаясь современной терминологией, председателем представительного органа муниципального образования. В нормах Городового положения не проясняет также и ситуацию по разграничению полномочий между, с одной стороны, городским головой, и, с другой стороны, между главой городского магистрата (ратуши), который по-прежнему функционировал как орган государственной власти в городах.

Дальнейшее правовое развитие института главы местного самоуправления связывается с известными реформами либерального толка второй половины XIX века, в рамках которых были осуществлены земская и городская реформами - на основе соответствующих законов. Речь идет прежде всего о следующих нормативно-правовых актах: Положение о губернских и уездных земских учреждениях (утверждено 1 января 1864 года) и Городовое положение (утверждена 16 июня 1870 года). В обоих случаях речь шла о коллегиальных органах местного самоуправления, соответственно председатели земских земских управ и городских управ также не имели собственных полномочий по решения вопросов местного значения и решали в основном организационные вопросы, связанные с проведением земских и городских органов самоуправления и реализацией принятых 
решений. В первые годы осуществления реформ возникали разного рода трудности, в том числе кадровые, особенно в провинции. В литературе в этой связи отмечалось, в частности, что в Удмуртии «из-за малочисленности дворян постоянно возникали трудности в подборе членов земских собраний гласных, в итоге состав земских учреждений вынужденно складывался из представителей других сословий» [7].

Несколько позже российский законодатель утвердил новые редакции указанных законов - Положение о губернских и уездных земских учреждений в редакции от 12 июля 1890 года [8] и Городовое положение в редакции от 11 июня 1892 года [9]). Изменения заметно уменьшали самостоятельность органов местного самоуправления и отражали так называемый процесс контрреформ в конце XIX века, однако в контексте исследуемой проблематики это не имеет принципиального значения, так как статус председателей земских собраний (земских управ) и городских собраний (городских управ) практически не изменился. В частности, глава МВД через свой совет и губернатор через подконтрольное ему губернское присутствие по земским делам получили право увольнять председателей и членов земских управ в дисциплинарном порядке [10, с. 14].

Рассмотрим некоторые полномочия председателей земских собраний на примере Положения о губернских и уездных земских учреждениях 1890 года. Так, в соответствии со ст. 96 как губернская, так и уездная земские управы имели статус исполнительных органов земского самоуправления. При этом указывалось, что земские управы состоят из председателя управы и нескольких входящих в ее состав членов в количестве до шести человек. Члены управ избирались земскими собраниями на срок в 3 года. Согласно ст. 120 Положения о губернских и уездных земских учреждений из числа членов управы земское собрание избирало председателя управы. Важно заметить, что члены управ могли быть лица, не являющиеся гласными (депутатами) земских собраний, но к ним предъявлялось требование - они должны были обладать активным избирательным правом. Из содержания данного закона следует, что решения земских управ принимались коллегиально и соответственно каких-либо особых полномочий у председателей управы не предусматривалось.

В ст. 117 Положения о губернских и уездных земских учреждениях определялись требования к претендентам на должность председателя управы, и таковых было немного, в частности, указывалось, что кандидат должен был иметь право поступления на госслужбу, далее формулировался запрет семейственности (в управе запрещалось быть членам «в первой степени свойства»). Избранный председатель управы не сразу вступал в должность он должен был быть утвержден в должности главой МВД (председатель губернской земской управы) или губернатором (председателем уездной земской управы). Если главой МВД и губернатором как представителями госвласти председатель земской управы не утверждался, то назначалось новое избрание председателя земской управы; если неутверждение повторялось, то председатель земской управы назначался указанными должностными лицами. Этот порядок показывает большую зависимость местного самоуправления от государственной власти [11, с. 26].

Следует далее заметить, что председатель земской управы имел право принимать участие в работе земских собраний на правах гласных, а председатель уездной земской управы, помимо этого, получал право участвовать в работе губернского земского собраниях, но без права решающего голоса. Согласно ст. 120 Положения о губернских и уездных земских учреждениях земское собрание избирало также «заступающего место председателя»), то есть, запасного председателя - на время временного отсутствия председателя (по болезни, командировке и т.д.). Другой важный аспект заключается в том, что председатели управ, равно как и члены управ, считались состоящими на государственной службе, и им полагались соответствующие первому классному чину мундиры, а также пенсионное обеспечение. Расходы на содержание председателей управ (также и членов управ) определялось Губернским по земским и городским делам Присутствием и не должно было превышать среднего по губернии оклада соответствующей 
должности. Увольнение председателя управы до истечения выборного срока по собственному желанию производилось лицами, которые их утверждали или назначали (то есть, глава МВД или губернатор). Что касается городского самоуправления, то там статус «городского головы» был аналогичен статусу председателя земской управы. Такой статус председателей управ в своей основе сохранялся до конца существования Российской империи. В дальнейшем, в советском государстве, институт главы местного самоуправления был упразднен и заменен институтом председателя исполнительного комитета местного Совета. При этом председатель земской (городской) управы) и председатель исполкома местного Совета по своему организационно-правовому статусу были во многом схожи, но при этом советская власть пошла дальше - председатель исполкома мог избираться только из числа депутатов и утверждения «сверху» было не нужно, правда, требовалось одобрения партийными инстанциями, и в целом демократии по организации местной власти в советском государстве было больше, другое дело, что в реальности нормы права зачастую расходились с практикой.

$$
* * *
$$

1. Агеева Я.К. Земские уставные грамоты XVI в. // Вопросы экономики и права. 2014. № 12. С. 20-23.

2. Загоскин Н.П. Наука истории русского права. Казань: изд. Илья-шенко, 1891. 530 с.

3. Лаптева Л.Е. Земские учреждения в России. М.: ИГиП РАН, 1993. 132с.

4. Беляев И.Д. Лекции по истории русского законодательства. М.: Изд. Петровского, 1879. 728 c.

5. Фадеева T.M. Российский абсолютизм в XVIII веке (аналитический обзор) // История России в современной зарубежной науке. 2013.№ 2. С. 173-201.

6. Городовое положение (Жалованная грамота на права и выгоды го-родам) от 21 . 04.1785 г. // Законодательство Екатерины 11. В 2 т. Т. 2. М.: Юридическая литература, 2000. С. 77-177.

7. Евдошенко И.В. Из истории становления земства в Вятской губернии // Вестник Удмуртского университета. Серия «Экономика и право». 2014. № 2. С.124-127.

8. Положение о губернских и уездных земских учреждений от 12.07. 1890г. // ПСЗ-3. Т. 10. № 6927.

9. Городовое положение от 11.06. 1892 г. // ПСЗ-3. Т. 12. № 8708.

10. Федунов В.В., Старицын А.В. Организационно-правовая деятель-ность Таврического губернского земства в 1887-1908 гг. // Актуальные про-блемы российского права. 2017. № 10. С. 11-18.

11. Шульженко Ю.Л. Реформы местного самоуправления в России (пе-риоды абсолютной, конституционной монархии, буржуазной Республики) // Труды Института государства и права Российской академии наук. 2014. № 5. C.24-33. 